Serce me daję. Archiwum Klarysek w Starym Saczu - 2, wydał i opracował J. Królikowski (Sądecka Góra Tabor, t. 8), Biblos, Tarnów 2012, ss. 106.

Językową formą utrwalenia doświadczeń i przeżyć wewnętrznych jest autobiografia duchowa (nazywana także dziennikiem duszy), w ramach której można mówić o wewnętrznie zróżnicowanym języku osobniczym - idiostylu. Przykładem takiej artystycznej organizacji tekstu są rękopisy stanowiące komentarz do cyklu rycin Cor Iesu amanti sacrum, które zostały zebrane i opublikowane przez ks. prof. Janusza Królikowskiego w postaci publikacji pt. Serce me daję. Ze względu na procesualność, na przedstawiony w nich tok przeżyć wewnętrznych, doznań oraz transformację myśli są one także pewnego rodzaju strumieniem świadomości, wewnętrznym monologiem bądź modlitwą osoby mówiącej. Ich celem nadrzędnym jest komunikacja z Bogiem, z Sercem Boga oraz nazywanie i interpretowanie tego, co stanowi istotę tej sytuacji komunikacyjnej.

Pełne zrozumienie zawartych w nich zapisów jest możliwe wtedy, gdy uzyska się wyjaśnienie, dlaczego użyto określonych środków leksykalnych i jaka jest ich organizacja ze względu na intencję twórcy tekstów oraz jego pragmatyczne zdeterminowanie wspomnianą sytuacją komunikacyjną. Istotą tekstu mającego znamiona biografii duchowej jest uchwycenie związku między językiem, jego wyznacznikami estetycznymi, a rzeczywistością wewnętrzną autora. Bez wdawania się w szersze konteksty osobowości twórcy tych tekstów można przyjąć, że z pewnością determinują one typologicznie (językowe) właściwości tych rękopisów. Można jednak domniemywać, że jest to osoba na co dzień związana z przestrzeniami sacrum, na co wskazywałby jej stan świadomości religijnej i specyficzny sposób widzenia rzeczywistości, kształtowanej przez ,życie według ciała” i ,życie według ducha”. To, czego doświadcza w świecie ziemskim, odnosi do rzeczywistości nadprzyrodzonej, przez co zyskuje ona nowy sens i nową wartość.

Biorąc pod uwagę czas powstania wspomnianych tekstów, warto uwzględnić tzw. kulturowy ideał osobowości autora, który ma silny związek z językowym sposobem wyrażania i utrwalania sensu i istoty osobistej wędrówki duchowej, mającej swe źródło w kontemplacji Serca Bożego. W tej przestrzeni duchowej powstaje językowy obraz ewolucji zapatrywań i postaw wobec świata zewnętrznego, całościowy sens doświadczeń duchowych, z których autor konstruuje swoistego rodzaju paradygmat rozmyślania, rozpamiętywania, medytacji i duchowego przyglądania się Sercu Bożemu w skupieniu. Warto w tym miejscu podkreślić komplementarny charakter biernego proces poznawania rzeczywistości duchowej przez autora z całościowym sensem egzystencjalnych doświadczeń. 
Analizowane teksty, które są reprezentatywne dla nurtu mistycznego, charakteryzują się wysokim stopniem obfitości słownikowej. Wysoka nominalizacja tekstów wynika $\mathrm{z}$ potrzeby uzewnętrznienia przeżyć wewnętrznych, a tym samym - z zarysowania duchowej drogi autora. Stąd autor chętniej korzysta z wyrazów atrybutywnych, za pomocą których wyraża najwyższą waloryzację Serca Boga. Uwagę zwraca obfita epitetyzacja przekazywanych treści, co wiąże się z dodatnią korelacją między rzeczownikami i przymiotnikami. Kontemplacja Serca Boga jest scenerią głębokich przeżyć wewnętrznych, o czym świadczy bogactwo leksykalne, które jest tym większe, im więcej w tekście znajduje się wyrazów pełnoznaczeniowych. Zajmują one miejsce szczególnie uprzywilejowane w językowym zapisie wędrówki duchowej autora. Nieobojętna jest też częstotliwość użycia pewnych słów kluczy, które są nośne ze względów symbolicznych i metaforycznych, jak również określają rodzaj wyobraźni autora analizowanej autobiografii duchowej. Przybliżają one wiele trudnych kontekstów, w których Serce Boga i serce człowieka staje się przestrzenią niełatwych zmagań religijnych i duchowych. Leksemy pełnoznaczeniowe to wyrazy - tematy, które są ściśle związane ze stanem osoby przeżywającej pewnego rodzaju doświadczenia mistyczne. Sygnalizując specyfikę składu leksykalnego, warto podkreślić, że jest ona ściśle związana z pozajęzykowymi determinantami komunikacyjnymi i podporządkowana normom gatunkowo-funkcjonalnym. Głęboka indywidualizacja podmiotu nadaje zebranym tekstom rys konfesyjny, odzwierciedlający w duchowo-estetycznej perspektywie świat jego wewnętrznych przeżyć, będący w opozycji widzialność - niewidzialność duchowa.

Funkcje estetycznego ukształtowania tekstów pełnią epitety ekspresywne, które pogłębiają stopień skontrastowania między tym, co boskie, a tym, co ludzkie, np.:

Krwia Twoją święta na kościot poświęcić,

A milość Twoję w nim ognista wzniecić (s. 16).

Złącz je i zjednocz z bolesnym na krzyżu Sercem Jezusowym, aby dotad Trojcy Naświętszej, Bogu mojemu, na tym oltarzu w ogniach mitości wdzięczna zawsze ofiara dożywotnie aż do śmiertelnego zawsze gorzało popiotu. Amen (s. 17).

Boże moj prawdziwy, Tworco moj wszechmogacy, Tyś Ojciec moj święty, Pan moj łaskawy, Krol moj wielki, pasterz moj dobry, nauczyciel moj nawierniejszy, pomocnik moj namożniejszy, chleb moj żywy, przewodnik moj nieomylny. Boże moj, Tyś jest prawdziwa świattość moja, stodkość moja nawdzięczniejsza, droga prosta, prawda spolna, żywot moj, straż i obrona nabezpieczniejsza (s. 18). 
O petne krwawych boleści ukrzyżowanego Jezusa ręce. O ręce dobrotliwe, jakoście wy mnie wiele dobrego czynity. Pelne laski wszelakiej, petne miłosierdzia boskie ręce Jezusowe, jakoście wiele dotad ze mna czynity milosierdzie, folgując, tak dlugo nie karzac grzechow moich, a jam jedna wszelkiej łaski Twojej, Boże moj, naniegodniejsza $i$ naniewdzięczniejsza grzesznica, tylem razy ranę na ranę boskim rękom Twoim zadawata, ilem razy moje przeciwko powtarzała złości (s. 32).

Celom ekspresywnym służą także poetyzujące neologizmy, które są środkami językowymi uwznioślającymi nienazwaną, niepoznawalną, niewidoczną rzeczywistość, wskazującymi na indywidualizm i chwilowość, ulotność i niepowtarzalność doświadczeń mistycznych podmiotu. Są czytelne w ramach kontekstu wypowiedzi. Mają charakter jednorazowy, a tym samym są konstrukcjami językowymi nieproduktywnymi, zatem można zaryzykować stwierdzenie, że są niespotykane $\mathrm{w}$ innych tego rodzaju przekazach, bo sygnalizują specyficzny charakter wypowiedzi (komunikatu). Należą do nich następujące przykładowe formacje językowe:

cierpienie - niezmierzone wszytkich boleści morza (s. 43), gorzkie morze (s. 44);

grzech - przykra gorzkość (s. 32), cień śmierci (s. 54), piekielna gadzina (s. 54), grob smrodliwy (s. 54), mieszkać w cieniu (s. 55), nieszczęśliwe ciemności (s. 56), ząb jadowity (s. 58), szatańskie więzienie (s. 58), ciemności lękliwe (s.58), rany sumienia (s. 59), mrok smutny (s. 82), sidła i sieci szatańskie (s. 88), kłamliwe zdrady obłudnego świata (s. 93);

kara - skarbnica gniewu (s. 34);

krzyż - krwawe łoże konania (s. 74), drzewo żywota (s. 76), łoże krolewskie (s. 76);

laska - źrodło słodkiego żywota (s. 32);

pokusa - grzechowa moc szatańska (s. 34), okrutna moc szatańska (s. 35);

szatan - lew ryczący (s. 89);

śmieré - chwała wiecznego widzenia (s. 34), tryumf żywota wiecznego (s. 39), zloty brzeg żywota wiecznego (s. 83), żywota potom (s. 85), morza świata nawałności (s. 95);

życie doczesne - ciężkie ciała mojego więzienie (s. 71); więzienie śmiertelne ciała (s. 82), nawałność morska tonących potopniow (s. 85).

Wyróżnione powyżej środki językowe mają charakter metaforyczny. Stanowią pewnego rodzaju siatkę semantyczną i nakładają się na rzeczywistość widzianą oczami osoby zaangażowanej medytacyjnie i kontemplacyjnie. Są one wyróżnikami konwencji charakterystycznej dla nurtu mistycznego. Leksyka ekspresywna, precyzująca duchowe doświadczenia podmiotu, wyznacza pewne pola wyrazowe poprzez relacje znaczeniowe pomiędzy leksemami oraz w obrębie pojedynczego jednoznacznego wyrazu. 
Serce Boga jest metaforą drogi nawrócenia człowieka. Na podstawie analizowanych tekstów można wskazać jej następujące etapy, będące świadectwem świadomości duchowej podmiotu, któremu za pomocą charakterystycznie ukształtowanego słownictwa został nadany specyficznie poetycki charakter:

I. Stary człowiek

Boże moj, miłości moja, jedyna nadziejo moja. Ach, coż mam mowić przed Toba? Byt czas, kiedym ja głosu Twego nie znała, znajac, stuchać nie chciała, stuchajac, nie petnita. Biada głuchocie nędznego serca mego. Biada czasowi onemu, godzinie onej, ktorym ja głosem twoim wzgardziła. O wymażże ja z czasu życia mego święta krwia Twoja, Korolu i Panie wszytkich wiekow, Jezu Chryste, Synu Boży, na wieki (s. 25).

[...]

Nieszczęśliwe ciemności, ktore kiedykolwiek zaćmily oczy duszy mojej, żem na Ciebie, Boże moj, wszędy i zawsze obecnego, nie patrzyła, żem Cię nie widziała na on czas, kiedyś Ty na wszytkie sprawy moje, na wszytkie serca mojego patrzyt skrytości $i$ widziateś wszytkie mysli $i$ żądze moje, i lepiej-eś je poznawat aniżeli ja, ktoram ich bez Ciebie, o światto prawdziwe, znać nie umiała (s. 56).

II. „Obumieranie starego człowieka"

O bodajże bym była pierwej nieczulym stata się kamieniem, niżelim kiedy ręce moje do grzechu na zranienie ręku twoich, Boże moj, ściagnęta. Żałuję tego jak najwięcej mogę. Żałuję, że wedtug godności, żałować i niszczeć w serdecznym moim nie moge żalu. Wyrzekam się wszytkich grzechow dla Twojej, Boże moj, miłości na wieki (s. 33).

$[\ldots]$

Pozwol narzekać sercu memu nad ghupstwem swoim. Daj, Boże moj, mowić przed soba ziemi i błotu; naucz mię, Panie moj, co i jako mam mowić do miłosierdzia Twego. Oddal ode mnie ciemności moje (s. 56).

III. Nowy człowiek

Krolu moj, Odkupicielu moj, Jezu Chryste, ukrzyżowany. Takie niech we mnie będzie królestwo twoje, o ktorymeś Ty sam powiedziat: „Krolestwo moje nie jest z tego świata”. Oddalize ode mnie wszytkie świata tego prożności; oddal serca wyniostość, czci, honorow $i$ bogactw pragnienie; oddal gniew, wszelaka zemste $i$ niespokojna serca gorzkość, a otocz mię tarcza pokory, cichości, cierpliwości Twojej, napetn serce moje wdzięczna łaskawościa i cichościa słodkiego ducha miłości Twojej (s. 49). 
$[\ldots]$

Nie gaśnijże nade mna, światłości wieczna, ktorej żadnej nigdy ciemności, żadna ćmić nie może ślepota. Otocz mię dokota, abym wszędy $i$ zawsze na Ciebie z każdy strony przytomnego patrzyta Boga. Proszę Cie przez Ciebie samego, Boże moj, światto moje prawdziwe, nie opuszczajże mię. Tyś mię stworzyt, gdym nie była. Odkupiteś mię, gdym byta zginęła. Byłam umarła, a Tyś mię śmiercia Twoja ożywit. Nie porzucajże mię między ciemności, abym w nich nie zginęta na wieki (s. 57).

Jak wcześniej wspomniano, analizowany tekst autobiografii duchowej jest odpowiedzią na kompozycję literacko-obrazową Serca Bożego, który wyjaśnia i rozwija duchowy i religijny sens obrazu. W związku z tym nie bez znaczenia są inspiracje przenośnych znaczeń „serca”, gdzie „serce” można rozumieć w znaczeniu fizycznym - zgodnym ze znaczeniem słownikowym, ale także jako perspektywę tych płaszczyzn, które są wzrokowo niepostrzegalne, gdyż dotyczą rzeczywistości nadprzyrodzonej, i są rozumowo niewyrażalne i niepoznawalne. Właśnie w tej przestrzeni słownej między niewyrażalnością a niepoznawalnością jest miejsce na kreatywną funkcję języka, mocą której powstają metaforyczne obrazy Serca Bożego, stanowiące sferę odniesienia do psychiki i ducha kontemplującego podmiotu.

Lektura publikacji ks. J. Królikowskiego skłania do refleksji nad rolą metafor w opisie doświadczenia religijnego, które są poetyckim sposobem wyrażania treści na nowo odkrytych. We wspomnianych rozważaniach duchowych, wspartych sztuką emblematyczną, szczegółowe znaczenie „serca” wynika każdorazowo z kontekstu, a pełniejsze rozumienie jego sensów przenośnych musi odwoływać się do refleksji teologicznych (biblijnych), które są inspiracją dla praktyki językowej, literackiej, codziennej (potocznej). Stąd można zauważyć nierzadkie biblijne powiązanie i odniesienia międzytekstowe, które autor wplata w swoje rozważania duchowe. Mają one znaczenie i sens, które można określić jako dialogowa relacja $\mathrm{z}$ tekstem głównym, przyjmująca czasami formę komentarza, np.:

„,Wszyscy stawić się musimy przed sadem Chrystusowym, aby odniost każdy wlasne sprawy ciała, jako czynit, lubo dobrze, lubo źle”, z 2 Listu do Koryntian, rozdziat 5,10.

Wierzę $i$ wyznawam, że nie tylko nieprawości, ale i wszytkie moje sprawiedliwości sądzisz będziesz, o straszliwy w rada[ch] Twoich nad synami ludzkimi, Boże. Ach, cóż czynić będę? Co poczniesz, co rzeczesz, mizerna duszo moja, kiedy w on straszliwy przy śmierci moment, $w$ on czas, gdy się między ciężkimi boleściami śmiertelnymi z konajacym ciatem twoim rozstawać będziesz. Wtenczas ze wszytkich złych i dobrych uczynków, słow i naskrytszych myśli serdecznych sprawować się przed strasznym sadem Chrystusowym musisz. Tam się okaża rozmnożone jak piasek morski nieprawości 
twoje i odkryja się zakryte grzechy twoje. Tam ich niezliczona liczbę, sprośność, brzydkość, szkaradność, niegodność i złość nieskończona jaśnie obaczysz, doskonale poznasz, lękać się, drżeć $i$ usychać od bojaźni będziesz (s. 40-41).

Na tym etapie rozważań wyraźnie widać związek sztuki plastycznej ze słowem, które zmaga się z mistyczną przestrzenią. Wiele kontekstów poświadcza to, że Serce Boga jest pojmowane przede wszystkim w znaczeniu niefizycznym i konotuje wszystko to, co jest skryte, prawdziwe - a nade wszystko - wewnętrzne w podmiocie kontemplującym. $Z$ tego punktu widzenia kontemplacja emblematyczna niewątpliwie sprzyjała myśleniu sercem - które jest zwierciadłem tego wszystkiego, co odnosi się do wiary, rozumienia, pragnienia, zamierzeń, jak również upowszechnieniu i utrwaleniu tego sposobu doświadczenia religijnego i duchowego. Zatem z funkcji przysługujących sercu w omawianych tekstach realizuje się również ta związana z sercem jako siedliskiem myśli i uczuć. Podmiot wypowiadający się wyraża to w następujący przykładowy sposób:

Szczęśliwe serce, w ktorym Bog kroluje,

W którym jako chce, co chce rozkazuje,

A dusza zaraz siłami wszytkiego

Serce chce petnić wola Boga swego.

Jaka tam radość, jakie uciszenie,

Jak wielki pokoj ma takie sumnienie.

$W$ szczęściu, w nieszczęściu serce się raduje,

Trudności nie zna, ciężkości nie czuje,

Stękać nie umie między boleściami,

$W$ smutku opływa zawsze pociechami.

Nie zna, co nędza, w niczym nie stęskuje,

Boska się zawsze wola kontentuje.

Ach, czemuż Boga ludzie nie mituja,

Czemu tak światu i ciału hołduja.

Wszytko swe szczęście czemu z Bogiem traca,

$A$ wieczna zgubę tak bogato płaca.

$O$ bodaj byto serce me nie znato

Tych Panow, ktorych procz Boga stuchato,

Ktorzy dokad mię w swej niewoli mieli,

$\mathrm{Na}$ wieki duszę moję zgubić chcieli.

Nie chce od tych czas nikogo inszego

Stuchać, mój Jezu, procz Ciebie samego.

Ty sam, laskawy Tworco moj i Panie,

Zasadź w sercu mym wieczne krolowanie.

Co chcesz, jak chcesz, rozkaż, a Twoimi

Pomoż wykonać rękoma własnymi (s. 47). 
Można zaryzykować stwierdzenie, że podmiot kontemplujący, weryfikując bieg swego życia, dochodzi do wniosku, że nie zawsze kategorycznie identyfikował swoje myśli i uczucia z Serem Boga. Stąd powstaje metafora przestrzeni serca, w której człowiek zdolny jest do przyjmowania aksjomatów Serca Boga do swego wnętrza. W świetle rozrachunku podmiotu wypowiadającego ze swoim życiem można mówić o konceptualizacji metaforycznej serca jako tworzywa podatnego na wpływy tego, co pożyteczne i bezpieczne dla stanu serca, albo opornego i twardego.

Istotna w budowie językowego obrazu nowej rzeczywistości - rzeczywistości duchowej - jest zmiana perspektywy widzenia, widoczna w posługiwaniu się nazwami antonimicznymi (życie cielesne - życie duchowe; mądrość - głupota; pycha - pokora). Umieszczenie określeń przeciwstawnych w odpowiednim kontekście doświadczenia mistycznego ujawnia różne miejsca desygnacji: Bóg - człowiek; ziemia - niebo; cielesność - duchowość. Natomiast pojęcia te wyznaczają kręgi semantyczne, budujące obraz doświadczenia mistycznego, i określają typ wartościowania rzeczywistości ziemskiej i niebiańskiej.

Poniższe zestawienie przedstawia przykładowe rodzaje określeń, które wartościują świat ziemski i świat duchowy. Potwierdzają one przekonanie, że językowy sposób interpretacji rzeczywistości za pomocą pojęć przekształca ją poprzez ujmowanie jej w zupełnie innych kategoriach semantycznych:

\section{rzeczywistość ziemska}

światowe prożności

marność, głupstwo i ślepota

sprośność grzechow

obrzydliwości

piekielna gadzina

nikczemne śmieci

wiatrami poburzone morze

rozmaite kłopoty, ciężkie frasunki, utrapienia ustawiczne, ludzkie nienawiści i nieprzyjaźnie, nędze, boleści, choroby, pokusy szatańskie, nawałności rozmaite, zalew gorzkości, utrapienia zwierzchnie ciała, boleści i wewnętrzne niepokoje potop świata

rzeczy stworzonych kłamstwa smrodliwe i ciężkie więzienia

\section{rzeczywistość niebiańska}

ożywiająca mądrość

korona chwały zwycięstwo tryjumfow nieporuszona $\mathrm{w}$ pośrod morza stoi skała brzeg naszczęśliwszy zbawienia wiecznego wesoła światłość napełniona naprzyjemniejszą wonnością 
Także wyliczenia, wymienianie i ewentualne opisywanie pewnych elementów świata ziemskiego i niebiańskiego sprzyja aksjologizacji tej rzeczywistości, która jest przedmiotem kontemplacji:

Rychłoż mię wprowadzisz do onego złotego miasta, do świętego domu Twojego, do onej wesela wiecznego stolowej izby, do wiecznego w niebie pokoju, gdzie zawsze jest żywot bez śmierci, zdrowie bez choroby, mlodość bez starości, wesele bez smutku, bezpieczność bez bojaźni, szczęście bez zazdrości, mitość bez nieszczerości, dzień bez nocy, jasność bez ciemności, zupetność pomyślnego szczęścia bez żadnego niedostatku, gdzie wszyscy święci z aniołami, ludzie w Bogu swoim wieczna zjednoczeni mitościa, wszelakich szczęśliwości, pociech, stodkości, wesela zażywać będa na wieki (s. 83).

Ty, o jedyne dobro dusze mojej, Jezu moj najdroższy, we krwi Twojej przenaświętszej zasiewasz w serce moje Twoję własna miłość, Twoje cierpliwość, cichość, wzgardę świata, czystość, postuszeństwo, laskawość $i$ wszytkie inne cnoty i doskonatości, i tego czekasz, ogrodniku moj drogi, by niemi jako naślicznemi i nawdzięczniejszymi kwiateczkami zakwitało serce moje (s. 98).

Oto ze wszytkiego dobra ztupiona od nieprzyjaciol stawiam przed Toba dusze moję. Oto powrozami grzechow swoich zwiazana, skrzywiona i zgarbiona pod ciężarem nieprawości, plugastwem ciężkich złości pokalana, od okrutnych zelżona i posromocona szatanow, zraniona, zgniła i śmierdzaca stoi przed Toba mizerna dusza moja (s. 101).

Punkt widzenia podmiotu kontemplującego jest więc nie antropocentryczny, ale teocentryczny. Ponieważ rozmyślanie nad rzeczywistością boską jest nie do zrozumienia i nie do poznania, autor analizowanych tekstów interpretuje to, co przeżywa, poprzez metafory i symbole. Doświadczenie duchowe, które odbiera, jest tak głębokie wewnętrznie i psychicznie, że wpływa na językowy odbiór rzeczywistości.

Nie bez znaczenia dla językowej kontemplacji emblematycznej są także wyrażenia przyimkowe typu:

ze mną - Nie raczże wchodzić ze mną na straszne sądy surowej sprawiedliwości Twojej (s. 41);

nade mną - Zmiłujże się nade mną, namiłosierniejszy Jezu Chryste (s. 41)

przed Tobą - Tobiem samemu zgrzeszyła i złość-em przed Tobą popełniła (s. 41);

ku Tobie - Jakoż ciężkiego wstydu i sromoty pełną podniosę twarz moję ku Tobie? (s. 41); 
na Cię - Jakoż na Cię, ktoregom tak wiele razy gniewała, patrzeć będę mogła (s. 41-42);

przed Tobą - Abym nigdy bez ciężkiego zawstydzenia przed Tobą nie śmiała ku niebu podnieść niegodnych oczu moich (s. 42);

we mnie - Niechajże we mnie daremne Jezusowe i Twoje nie będą boleści. Niech prożna nigdy we mnie nie będzie żadna Boga mego łaska krwawa męki i śmierci Jezusa, Syna Twego, wysługa (s. 43);

przez mię $-[\ldots]$ żeby przez mię, we mnie i we wszytkim stworzeniu, z zupełnym mnie samej zawsze we wszytkim wyniszczenim sam Bog nawiększy był wyniesiony chwały dożywotnie i na wieki (s. 44).

Poświadczają one o stałej horyzontalno-wertykalnej relacji Bóg - człowiek w duchowej refleksji podmiotu, który jest połączony $\mathrm{z}$ odpowiednim rodzajem honoryfikatywności, znamionującym w tym przekazie relacje dystansu i szacunku. Ilustrują one również pewien rodzaj procesu, w którym kontemplowanie Boga wyzwala między uczestnikami dystans połączony z formą pewnej językowej estymy, atencji i wytworności. Jest to również efekt wgłębienia się w Osobę kontemplowaną i przeniknięcia emocjami temu towarzyszącymi.

Nie sposób nie zauważyć, że teksty zebrane przez ks. prof. J. Królikowskiego są pewnego rodzaju autobiografią duchową, realizowaną $\mathrm{w}$ formie modlitwy kontemplowania oczami i sercem. Istotnym zjawiskiem, z punktu widzenia aktu komunikacji i jego konkretnej pragmatycznej realizacji, jest język religijny (język sacrum). Jego wyznacznikiem w analizowanym materiale jest przywoływanie i opisywanie przez człowieka rzeczywistości nadprzyrodzonej za pomocą specyficznie dobranego i ukształtowanego słownictwa, którego cechą dystynktywną jest intencjonalność, mającą podkreślać szczególną sytuację religijną podmiotu wypowiadającego się. Intencjonalność wyraża się w ukształtowaniu stylistycznym wypowiedzi i towarzyszy kontemplacyjnemu wymiarowi przekazu.

Swoisty kontekst wiary, do którego permanentnie odnosi się autor doświadczeń religijnych, nakazuje wyróżnić Boga - jako uczestnika aktu komunikacji, co w konsekwencji wyjaśnia występowanie słownictwa odnoszącego się do sfery mistycznej. W planie treści skutkuje to wyraźną jej indywidualizacją, emocjonalnością, doniosłością i wewnętrznym przeżyciem.

Dotychczasowe rozważanie upoważniają do zastanowienia się nad językowym obrazem tożsamości osoby - człowieka zjednoczonego z Bogiem $\mathrm{w}$ akcie kontemplacji. Na podstawie wyekscerpowanych z całości autobiografii duchowej pewnych fragmentów wypowiedzi można zrekonstruować obraz Serca Boga i osoby wypowiadającej się oraz dostrzec, jak przedstawia się relacja między nimi. Oto przykłady wypowiedzi ukazujących otchłań i przepaść między Stwórcą a stworzeniem: 
O słodkości moja jedyna, nastodszy Jezu, przez wszytkę dobroć naświętszego serca Twojego niegodna (s. 29).

Przez one niezmierne Twoje, Jezu Chryste, Synu Boży, boleści, z ktorymi się święte ręce Twoje mordowaty, kiedy ostrymi do krzy$\dot{z}$ a przybite byly gwoździami, prosze, niegodna grzesznica, nie porzucaj mię, Boże moj, Tworco moj, Zbawicielu moj (s. 34).

Oto i ja naniegodniejsza pokornym na twarz moje przed Toba upadam sercem. [...] Niechaj zawsze w tęskliwym i nieskromnym pragnieniu ustaje do Ciebie, o jedyne dobro moje, Boże moj, nędzna dusza moja, dokad w blogosławionym chwaty wiecznej widzeniu Toba samym na wieki nie zostanie ukontentowana (s. 34-35).

O Boże moj, żywocie moj, jedyny Boże moj, świattości moja, raczże oświecić ślepote moję. [...] Mizerna duszo moja, czemuż ty o tym nie myślisz, jako i kiedy, doką z tego zgniłego i śmierdzacego cielska wynidziesz. [...] Co sobie pomyślisz, kiedy przed toba stana wszytkie grzechy i nieprawości twoje, stanie śmierć straszliwa, grob w ziemi ciemny, zgnitości, smrodu i robactwa petny, otwarte gorejace pod Toba piekło. Stanie nad toba Bog rozgniewany (s. 36).

Ach, mnie, mizernemu stworzeniu Twojemu, o dobrotliwy Boże. Ach, mnie nieszczęśliwej przed Toba, Boże moj, grzesznej. Gdzieże się dni żywota mojego podziały? O jakom wiele straciła dobrego, jakem wiele dopuściła złego. Jakem wiele razy Ciebie grzechami moimi dobrego obraziła Boga. [...] O Boże, Boże moj Boże Tworco moj wszechmogacy, nie porzucajże mię w onę straszna godzine, nie daj we mnie ginać na wieki dobroci Twojej (s. 37).

Ach, mię biada, mnie nieszczęśliwy grzesznicy. Jakoż stanę przed straszliwym, Boże moj, sądem Twoim? Jakoż ciężkiego wstydu i sromoty petna podniose twarz moję ku Tobie? Jakoż na Cię, ktoregom tak wiele razy gniewata, patrzeć będę mogta. [...] Abym nigdy bez ciężkiego zawstydzenia przed Toba nie śmiała ku niebu podnieść niegodnych oczu moich. Boże, badź miłościw grzesznej duszy mojej (s. 41-42).

O Panie, Krolu moj nataskawszy, Boże moj, jam jest stuga Twoja, jam stuga Twoja i corka stużebnicy Twojej (s. 48).

Powiedz namilosierniejszy, nałaskawszy, nadobrotliwszy, powiedz, jedyna dobroci moja, Boże moj, coś Ty jest, naniegodniejszej stużebnicy Twojej [...]. Ach, grzeszne serce moje, tyś jest nieszczęśliwa wszelkiej nędze przepaści, straszne i okropne cierniow śmierci 
mieszkanie. O serce moje, jaskinio i straszne piekielny gadziny tożysko (s. 59).

Oto my sq dzieło dobrotliwych ręku Twoich, mizerni twoi po ziemi czolgamy się robaczkowie (s. 86).

Oto powrozami grzechow swoich zwiazana, skrzywiona i zgarbiona pod ciężarem nieprawości, plugastwem ciężkich złości pokalana, od okrutnych zelżona i posromocona szatanów, zraniona, zgnita i śmierdzaca stoi przed Toba mizerna dusza moja (s. 101).

Warto zauważyć, że w tym szczególnym dokumencie językowy wizerunek Boga i człowieka jest konotowany w określeniach cech i nazwach, które podkreślają ogromną przepaść i dystans między „mizernym, ślepym i głuchym sercem” człowieka a „naświętszym sercem Boga”. Ta nieprzystawalna i antonimiczna relacja między Bogiem a człowiekiem tłumaczy fakt, że większość zbioru określeń i pojęć jest odnotowanych na określenie Serca Boga, a które wypowiada człowiek. Kim jest, kogo adoruje homo misticus i jakie są relacje między nimi, ukazują następujące sformułowania:

O Trojco nachwalebniejsza, jedyny Boże, Panie i Twórco (s. 17); Przenaświętsza, przenachwalebniejsza, nierozdzielna Trojco, Ojcze, Synu i Duchu Święty, prawdziwy Boże (s. 18); Tyś Ojciec moj święty, Pan moj łaskawy, Krol moj wielki, pasterz moj dobry, nauczyciel moj nawierniejszy, pomocnik moj namożniejszy, chleb moj żywy, przewodnik moj nieomylny (s. 18); nadobrotliwszy Panie (s. 24); nieprzebrany w miłosierdziu Twoim Boże (s. 24); Boże moj, jedyne $i$ wszytko dobro i szczesście moje na wieki. O stodka mitości i mita stodkości, Boże moj, [...] Panie, pocieszycielu moj, wesele moje [...], Boże moj, świattości moja nawdzięczniejsza, prawdo moja nieomylna, Boże wspomożycielu (s. 30); Panie chwaty wiecznej (s. 34); Panie śmierci i żywota (s. 36); nałaskawszy, namiłosierniejszy, o nigdy na wieki w nieskończonym mitosierdziu twoim nieprzebrany Boże (s. 41); wszechmogacy Tworco moj, Pan i dobrodziej moj (s. 41); Krolu moj, odkupicielu moj, Jezu Chryste (s. 49); Panie moj nadobrotliwszy, Ojcze nałaskawszy, Boże moj, miłosierdzie moje, nadziejo moja, świattości moja, żywocie, którym wszytko żyje, a bez którego wszytko obumierać musi (s. 57); Ty, nasprawiedliwszy Sędzio, Jezu Chryste, Synu Boży (s. 66); Panie śmierci i żywota, Jezu Chryste, prawdziwy Boże, sędzia nasprawidliwszy żywych $i$ umarłych (s. 69); O Boże moj, jedyna miłości moja, kochanie i pociechy, radości $i$ wesela, jedyne szczęście, dobro jedyne moje, Boże moj na wieki (s. 82); Boże moj, wspomożycielu moj, jedyna obrono i nadziejo moja [...], miłosierdzie moje [...], ucieczko moja (s. 89). 
Powyższym atrybutom Boga sa przypisane określone czynności, poprzez które okazuje On swoją moc sprawcza, podkreślająca bierność czlowieka i catkowite zdanie się jego na działanie Stwórcy:

[...] oddal ode mnie wszytkie złe pożadliwości, myślom gniewnym i mściwym nie dopuszczaj się szerzyć w sercu moim. Świeć zawsze duszy mojej, jasności moja, abym nie zbładziła $w$ niewiadomościach śmierci wieczny (s. 57).

O wszechmogaca siło moja, podepc we mnie wszytkie żądze złe, podepc wszytkie nie wedtug woli Twojej afekty i skłonności serca mego. Podepc miłość własna, pychę, gniewliwość i to wszytko, cokolwiek się boskim oczom Twoim podobać nie może (s. 59).

Zmituj się, Boże moj. Oświeć, ożyw, oczyść z plugastwa grzechow moich serce moje, aby się Tobie podobać mogło dożywotnie i na wieki. [...] Ratuj mię. [...] Podnieś mię z upadku mojego. Wyprowadź z cieniu śmierci. Wróć mi światto oczu moich. Uzdrow choroby moje, zlecz zranienia serca mego, albowiem Tyś jest nadzieja moja (s. 60).

Czekając, czekałam Pana i pospieszyt się na ratunek moj. Wystuchat wolanie moje $i$ wyprowadzit mię z głębokości nędze mojej i z blota wywiódt mie grzechow moich. Postawit na opoce nogi moje. Naprostowat ścieżki moje. Wyrwat mie z okrutnych ręku nieprzyjaciot moich (s. 61).

Napetnij serce moje, wszytkie sity moje, wszytkie członki ciała mojego, niezmierna boleścia i gorzkim żalem, [...] nienawiścią. Obróć na mię to wszytko, [co] dusze i ciało moje, honor moj, trapić, dręczyć, niszczyć dożywotnie może (s. 72).

Ukrzyżuj dusze i ciało, wszytkie dusze i ciała mego siły. Ukrzyżuj wszytkie zmysty i członki moje. [...] Uniżaj, napokorniejszy Jezu, wyniostość serca mojego (s. 77).

Zbaw mię, Zbawicielu moj drogi, przez zbawienne naświętsze Imię Twoje Jezus, aby we mnie taska i milosierdzie Twoje byto na wieki uwielbione [...], spuśćże się w serce moje, zapal je mitościa Twoja, napetnij je wszelkimi taskami, wznieć $w$ duszy mojej święte żądze i nigdy niezgaszone pragnienia, aby nimi dożywotnie gorzeć serce moje nie przestawato (s. 83-84).

Wybaw mię z sieci i sidet szatańskich, wyrwij mię z ręku okrutnych, wejrzyj łaskawym i miłosiernym okiem, nie oddalaj się ode mnie, ale racz być Bogiem obrońca moim, abyś mię zbawit (s. 90). 
W powyższych fragmentach wypowiedzi zwraca uwagę dynamika przeciwieństw sytuacji, w której znajduje się człowiek i tej, którą stwarza Bóg. Oddają to wyrażenia czasownikowe, które poświadczają także o sensulanym wymiarze doświadczenia religijnego. Wskazują na stan uniżenia, zależności, oczekiwania, ukorzenia się podmiotu mówiącego. Z kolei wszystko to, co wiąże się z aktywnością, ze stwarzaniem, działaniem, inicjowaniem, wprawieniem w ruch, kreowaniem - jest właściwością Boga.

Zarysowany szkic rozważań nad publikacją ks. prof. J. Królikowskiego Serce me daje poświadcza o bogactwie aspektów teologicznych i nieteologicznych (kulturowych) tego rodzaju tekstów mistycznych. Istnieje potrzebna analizowania językowego obrazu doświadczenia religijnego ze szczególnym uwzględnieniem jego genus proximum oraz jego differentia specifica. $\mathrm{Z}$ językoznawczego punktu widzenia interesujące wydaje się zbadanie sposobu zwerbalizowania tego, co trudne do zrozumienia ze względu na granice wyrażalności $\mathrm{w}$ języku, a takim ograniczeniom podlega tekst o charakterze mistycznym. Osoba wypowiadająca się nie znajduje odpowiednich desygnatów dla oddania tego, co stanowi istotę jej myśli, przeżyć i odczuć, dla tego, co chce powiedzieć. Zatem niewystarczalność języka werbalnego sprawia, że powstają osobliwe konstrukcje językowe pozbawione komunikatywności, paradoksalne, alegoryczne, przesycone metaforycznością, które zwracają uwagę dynamicznością przekazywanych treści, estetyką przeżyć i nowatorstwem utrwalania doświadczenia religijnego. Stanowią one także istotne kryterium wartości języka oraz są wyznacznikiem walorów mistycznych przekazu, wyznaczających specyficzny wzorzec zachowań komunikacyjnych.

Biorąc pod uwagę „mistyczne zmagania ze słowem”, których efektem są ewenementy słowne, szczególnego rodzaju neologizmy, poetyzmy, budujące obraz przeżyć duchowych, można mówić również o świadomości językowej osoby związanej z przestrzenią mistyczną. Nie bez znaczenia są również językowe sposoby uzewnętrznienia doświadczenia wewnętrznego, decydujące o przynależności tekstu do nurtu mistycznego. One to sytuują przekazywane treści na granicy wyobrażalności, „między” wyrażalnością a niewyrażalnością, a czasami wręcz niedorzecznością czy nielogicznością. Warto podkreślić, że one to utrwalają nieprzemijający sens i niezwykłość oraz nadzwyczajność doznań mistycznych. Osłaniają wewnętrzną dynamikę doświadczenia religijnego.

Językowy zapis duchowej wędrówki osoby, którą można domniemywać przez pewien znamienny sposób mówienia, jest przykładem na bogactwo różnorodnych realizacji języka religijnego w konkretnej sytuacji komunikacyjnej, jaką jest kontemplacja Serca Bożego, inspirowana cyklem rycin Cor Iesu amanti sacrum. 